\title{
INFLUENCE OF TIME MANAGEMENT IN MODELING OF CURVE RESISTANCE TO THE PENETRATION OF A LATOSOL UNDER DIFFERENT USES AND MANAGEMENT OF PASTURES AND NATIVE WOODLAND ${ }^{1}$
}

\author{
Kathleen Lourenço Fernandes ${ }^{2 *}$, Adriana Aparecida Ribon ${ }^{3}$, João Tavares Filho ${ }^{4}$, Gustavo Dias Custódio ${ }^{5}$ \\ and Leonardo Rodrigues Barros ${ }^{5}$
}

\footnotetext{
${ }^{1}$ Received on 10.11.2014 accepted for publication on 10.03.2016.

${ }^{2}$ Universidade Estadual de Goiás, Graduando em Engenharia Agronômica, Palmeiras de Goiás, GO - Brasil. E-mail: <kathleen_agro@hotmail.com>.

${ }^{3}$ Universidade Estadual de Goiás, Departamento de solos, Campus Palmeiras de Goiás, Palmeiras de Goiás, GO - Brasil. E-mail:<adriana.ribon@ueg.br>.

${ }^{4}$ Universidade Estadual de Londrina, Departamento de Agronomia, Centro de Ciências Agrárias, Londrina, PR - Brasil. E-mail:<tavares@uel.br>.

${ }^{5}$ Universidade Estadual de Goiás, Graduando em Engenharia Agronômica, Palmeiras de Goiás, GO, Brasil. E-mail: <gustavo.dias.custodio@gmail.com>and <leonardoagro92@hotmail.com>.

*Corresponding author.
}

\begin{abstract}
The soil resistance to penetration study helps in understanding the state of soil compaction, indicating how best to manage it. The present study aimed to verify the influence of time management in modeling curves of resistance to penetration in Oxisol under different uses and management of pastures and woodland in field conditions, using the stepwise procedure. The study was conducted in the Cerrado region. Five (5) systems of uses and management of pastures and native woodland were evaluated: ILPF: crop-livestockforest integration; ILP: crop-livestock integration; P: Area in the extensive grazing system; MN: native woodland; PIQ: rotated picket. The experiments were assessed for the years 2012/13 and 2013/14. To obtain the models, an analysis with four independent variables was performed: Gravimetric moisture (X1), bulk density (X2), total porosity (X3) and organic matter (X4) and the dependent variable, soil resistance to penetration (Y). The multiple regression analysis by STEPWISE with F of 0.15 was used. The equation that best estimated the resistance to penetration was $\mathrm{RP}=14.68$ to 0.26 for Native Woodland in layers from $0.20-0.40 \mathrm{~m}$ with R2 indices of 0.97 in year 1 . For year 2, the equation that estimated the resistance to penetration was obtained in the PIQ treatment, $\mathrm{PR}=-15.94-0.29 \mathrm{PT}+15.87 \mathrm{DS}+0.05 \mathrm{MO}$. with R2 of 0.94 .
\end{abstract}

Keywords: Soil compaction; Soil density; Total porosity.

\section{INFLUÊNCIA DO TEMPO DE MANEJO NA MODELAGEM DA CURVA DE RESISTENCIA À PENETRAÇÃO DE UM LATOSSOLO SOB DIFERENTES USOS E MANEJO DE PASTAGENS E MATA NATIVA}

\begin{abstract}
RESUMO - O estudo resistência do solo a penetração auxilia na compreensão do estado de compactação do solo, indicando a melhor forma de maneja-lo. O presente estudo teve por objetivo verificar a influência do tempo de manejo na modelagem das curvas de resistência do solo à penetração em Latossolo submetido a diferentes uso e manejo de pastagens e mata nativa em condições de campo, utilizando o procedimento de stepwise. O estudo foi realizado na região do Cerrado. Foram avaliados 5 sistemas de uso e manejo de pastagens e mata nativa: ILPF: integração lavoura-pecuária-floresta; ILP: integração lavoura-pecuária; P: Área de pastagem no sistema extensivo; MN: mata nativa; PIQ: piquete rotacionado. Foram avaliados os anos de experimentos 2012/13 e 2013/14. Para a obtenção dos modelos foi realizada uma análise com quatro variáveis independentes: umidade gravimétrica (X1), densidade do solo (X2), porosidade total (X3) e matéria orgânica (X4) e a variável dependente, resistência do solo à penetração $(Y)$. Foi utilizado a análise
\end{abstract}


de regressão múltipla por STEPWISE com $F$ de 0,15. As equações que melhor estimaram a resistencia do solo a penetração foi a $R P=14,68$ - 0,26 PT para a Mata Nativa na camada de 0,20 - 0,40 m com indices $R 2$ de 0,97, no ano 1. Para o ano 2 a equação que melhor estimou a resistencia do solo a penetração foi obtida no tratamento PIQ, RP = - 15,94-0,29PT + 15,87 DS + 0,05 MO, com R2 de 0,94. Ao longo de um ano os sistemas de manejos adotados proporcionaram melhora na qualidade fisica do solo. No segundo ano de experimento foi observada relação positiva da densidade do solo com a resistência do solo a penetração e negativa com umidade gravimétrica do solo.

Palavras-chave: Compactação do solo, Densidade do solo, Porosidade total.

\section{INTRODUCTION}

Most of the Cerrado biome is covered by pastures and most of those parts are nowadays in some sort of degradation, generally because of alterations in the soil's physical quality. To better these qualities, one needs to know the relationships among the physical properties of the soil, such as resistance of the soil to penetration, soil density, and total porosity, including moisture and organic matter levels.

The soil's resistance to penetration is an important attribute to be inferred, for it has direct correlation with the effects of machinery and is affected by the soil's density, total porosity, organic matter and moisture (TAVARES FILHO et al., 2012). Because of such relationships, the study of soil's resistance to penetration, among other attributes, is of fundamental importance for choosing the best system for soil preparation (RIBON; TAVARES FILHO, 2008) or management system, in already cultivated soils, favours the maintenance of its physical qualities.

Therefore, there is need of research that explain such relationships and quantify those with the passing of time, monitoring the alterations of physical qualities in different systems of use and management of pastures. Knowing that the management practices must promote good physical conditions over time, being modified by the initial preparation system of (ALBUQUERQUE et al., 2001).

Such studies are capable of comparing the physical quality of the altered soil with that of the one under forest, monitored and given opportunity to better management practices and soil conservation in a manner that increases its capacity to sustain a competitive productivity (ARAUJO et al., 2007). However, so that these studies can be validated, some authors explain that an adequate sampling in different moisture conditions is necessary (TAVARES FILHO; RIBON, 2008; RIBON; TAVARES FILHO, 2008).

Revista Árvore, Viçosa-MG, v.40, n.3, p.519-527, 2016
There is various literature that mentions the use of models or functions that identify the physical quality of the soil and demonstrate its influence over the compaction of the tropical soil is diverse ((IMHOFF et al., 2000; LEONEL et al., 2007; LIMA et al., 2007; RIBON; TAVARES FILHO, 2008; TAVARES FILHO et al., 2012). However, the choice of statistical method influences the handling of the data. Stepwise has been the model with best acceptance and it has been used in many studies of tropical soil. According to Ribon et al. (2014), the sepses procedure was the most adequate for obtaining the final models used to estimate the physical quality of a Red eutroferric Latosol under perene cultivation.

The present study had as an objective to verify the influence of time management on the modelling of the resistance to penetration curves of the soil in Latosol submitted to different systems of use and management of pastures and native woodland in field conditions, utilizing the stepwise process.

\section{METHODS AND MATERIALS}

The experiment was conducted at Luz da Vida, located in the county of Campestre-GO (Max. Lat. $16^{\circ} 46,472^{\prime}$ and Min. Long. 49 44,966'). The local soil was classified according to the Embrapa specifications as a Yellow typical Latosol, quite clayey, anthropic A, oxidic kaolinitic (EMBRAPA, 2013). Table 1 presents the soil's granulometry for the studied layers.

The study of the variables was organized in a delineation of blocks entirely casualized in subdivided parcels, the main treatments being 5 parcels with different systems of use and management of pastures and native woodland. 20 samples/treatments were collected in two of the soil layers $(0-0.20 \mathrm{~m}$ and $0.20-0.40 \mathrm{~m})$. Totalling, in 2 years of experimentation, year $1(2012 / 13)$ and year $2(2013 / 2014), 440$ samples. Each treatment presented an area of $1800 \mathrm{~m}^{2}$. 
Table 1 - Analysis of typical granulometric Oxisoil to the layers of 0-0.2 and 0.2-0.4 m.

Tabela 1 - Análise granulometrica do Latossolo Amarelo Distrocoeso típico, muito argiloso, A antrópico, cauliníticos oxídico, para as camadas de 0-0,2 e 0,2-0,4m.

\begin{tabular}{lccc}
\hline Layer & Sand & Silt & Clay \\
\cline { 2 - 4 } & & $\mathrm{g} \mathrm{Kg}^{-1}$ & \\
\hline $0-0.20 \mathrm{~m}$ & 400 & 80 & 520 \\
$0.20-0.40 \mathrm{~m}$ & 300 & 80 & 620 \\
\hline
\end{tabular}

The treatments were established in the following way on year 1 :

- ILPF: Area with crop-livestock-forest integration, with eucalyptus spaced at $3.0 \times 1.5 \mathrm{~m}$ for 6 years, and implantation of the joint soy-brachiara on the barreirão sistem and corn-brachiara after the soy harvest;

ILP: seeding area under conventional preparation after pasture dessication (Brachiaria decumbens with eight implantations) and corn planting after soy harvest, with posterior pasture formation again.

- P: Pasture area with Brachiara grass destined for animal grazing with 8 years of usage;

PIQ: rotated picket with Mombasa grass destined for animal grazing, implanted in 4 years, with animal rotation every 24 hours.

- MN: native woodland (permanent natural preservation area).

On year 2 , the only alteration was the removal of the eucalyptus in ILPF treatment and usage of fire as a mean of cleaning the area.

The soil's resistance to penetration was evaluated via the use of the IAA/PALNALSUCAR impact penetrometer model, as described by Stolf(1983), with a total of 10 repetitions. The data obtained by impact/ $\mathrm{cm}$ of soil was transformed in dynamic resistance $(\mathrm{MPa})$ via the proposed formula by Stolf(1991). At the moment of determination of soil's resistance to penetration (RP), samples were collected to determine the gravimetric moisture (UG), soil density (DS), total porosity (PT) and organic matter's levels (MO), determined according to the methods proposed by Embrapa (2011).

DS was determined by Kopecks ring method. A $63 \mathrm{~cm}^{2}$ ring was used. PT was determined by obtaining the particle density by the $50 \mathrm{ml}$ volumetric flask method.
MO was obtained by the organic carbon values obtained by oxidation of organic matter wet with potassium dichromate in a sulfuric acid medium.

For obtaining the models, an analysis will be realised with 5 independent variables represented by: gravimetric moisture (X1), soil density (X2), total porosity (X3) and organic matter (X4), and the dependent variable characterized by the soil's resistance to penetration (Y).

Normal distribution tests were applied for the selection of the participating variables of the model, excluding those that did not present a regular value distribution. Following that, simple correlation analysis between the variables and multiple regression analysis were done by STEPWISE, using the model preparation procedure of the SISVAR software, to model the effects of the properties under those conditions.

The level of significance of $F$ value for the variable of $15 \%$ probability for inclusion and exclusion of the model variables was used. The significance value of $15 \%$ was used because those were collected in real field situations (non-controlled environments) and according with the work of Dias et al. (1999). The models obtained under 2012/2013 were compared with those obtained from the $2013 / 14$ period to verify the influence of time management on the inclusion or exclusion of the variables participating in the models.

\section{RESULTS}

In the first year of evaluations (2012/13), higher coefficients of variations (CV) for RP variable were observed, followed by $\mathrm{MO}$, in all treatments in layers of $0-0.20 \mathrm{~m}$ and $0.20-0.40 \mathrm{~m}$, as can be seen in Table 2 .

The maximum RP values were observed in PIQ in both analysed layers. In this treatment, high DS values were also observed, with averages of $1.65 \mathrm{Mg}$ $\mathrm{dm}^{-3}$ and $1.62 \mathrm{Mg} \mathrm{dm}^{-3}$ for layers $0-0.20 \mathrm{~m}$ and 0.20 -0.40 , respectvively. Indicating this to be the most compacted treatment.

The treatments with lowest averages of RP and DS were ILP and ILPF, with values between 3.00 to $4.50 \mathrm{MPa}$ and 1.70 to $1.95 \mathrm{Mg} \mathrm{dm}^{-3}$, respectively. The RP values for those treatments were lower than those observed under MN, with averages of 5.25 and 5.49 $\mathrm{MPa}$ in layers $0-0.20 \mathrm{~m}$ and $0.20-0.49 \mathrm{~m}$, respectively.

Revista Árvore, Viçosa-MG, v.40, n.3, p.519-527, 2016

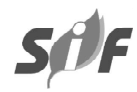


Table 2 - Statistical moments of year 1 for any variable at layers 0-0.2 and 0.2-0.4 $\mathrm{m}$ for soils under different land use systems and soil management and native woodland.

Tabela 2 - Momentos estatísticos do ano 1 para as variáveis analisadas nas camadas de 0-0,2 e 0,2-0,4m, para solos submetidos a diferentes sistemas de uso e manejo do solo e mata nativa.

\begin{tabular}{|c|c|c|c|c|c|c|c|c|}
\hline Layer $(\mathrm{m})$ & Variables & Ave. & $\mathrm{SD}$ & $\mathrm{CV}$ & Mod & Max. & Min & $\mathrm{N}$ \\
\hline \multicolumn{9}{|c|}{ ZCrop-livestock integration } \\
\hline \multirow[t]{5}{*}{$0-0.20$} & $\mathrm{RP}(\mathrm{MPa})$ & 3.25 & 1.27 & 0.39 & 2.63 & 6.07 & 1.25 & 20 \\
\hline & $\mathrm{Ug}\left(\mathrm{kg} \cdot \mathrm{kg}^{-1}\right)$ & 0.15 & 0.03 & 0.17 & 0.17 & 0.20 & 0.1 & 20 \\
\hline & Ds $\left(\mathrm{Mg} \cdot \mathrm{dm}^{-3}\right)$ & 1.81 & 0.14 & 0.08 & 1.87 & 2.05 & 1.48 & 20 \\
\hline & $\mathrm{PT}\left(\mathrm{cm}^{3} \cdot \mathrm{cm}^{-3}\right)$ & 27.47 & 6.59 & 0.24 & 28 & 40.14 & 13.75 & 20 \\
\hline & $\operatorname{Mo}\left(\mathrm{g} \cdot \mathrm{kg}^{-1}\right)$ & 24.9 & 5.76 & 0.23 & 29.00 & 33.00 & 14 & 20 \\
\hline \multirow[t]{5}{*}{$0.20-0.40$} & $\mathrm{RP}(\mathrm{MPa})$ & 4.49 & 1.31 & 0.29 & 4.01 & 8.83 & 3.32 & 20 \\
\hline & $\mathrm{Ug}\left(\mathrm{kg} \cdot \mathrm{kg}^{-1}\right)$ & 0.15 & 0.02 & 0.13 & 0.15 & 0.18 & 0.10 & 20 \\
\hline & Ds $\left(\mathrm{Mg} \cdot \mathrm{dm}^{-3}\right)$ & 1.92 & 0.08 & 0.04 & 1.97 & 2.07 & 1.74 & 20 \\
\hline & $\operatorname{PT}\left(\mathrm{cm}^{3} \cdot \mathrm{cm}^{-3}\right)$ & 23.62 & 4.51 & 0.19 & 20.00 & 31.17 & 16.25 & 20 \\
\hline & Mo $\left(\mathrm{g} \cdot \mathrm{kg}^{-1}\right)$ & 15.85 & 3.32 & 0.21 & 17.00 & 26.00 & 11.00 & 20 \\
\hline \multicolumn{9}{|c|}{ Extensive grazing } \\
\hline \multirow[t]{5}{*}{$0-0.20$} & $\mathrm{RP}(\mathrm{MPa})$ & 9.86 & 3.75 & 0.38 & 7.45 & 16.41 & 1.94 & 20 \\
\hline & $\mathrm{Ug}\left(\mathrm{kg} \cdot \mathrm{kg}^{-1}\right)$ & 1.14 & 4.28 & 3.74 & 0.16 & 19.8 & 0.13 & 20 \\
\hline & Ds $\left(\mathrm{Mg} \cdot \mathrm{dm}^{-3}\right)$ & 1.77 & 0.11 & 0.06 & 1.82 & 1.94 & 1.40 & 20 \\
\hline & $\operatorname{PT}\left(\mathrm{cm}^{3} \cdot \mathrm{cm}^{-3}\right)$ & 27.15 & 5.57 & 0.21 & 24.00 & 43.87 & 18.56 & 20 \\
\hline & $\operatorname{Mo}\left(\mathrm{g} \cdot \mathrm{kg}^{-1}\right)$ & 37.6 & 15.90 & 0.42 & 40.00 & 92.00 & 21.00 & 20 \\
\hline \multirow[t]{5}{*}{$0 . .20-0 . .40$} & RP (MPa) & 8.27 & 2.42 & 0.29 & 8.14 & 15.03 & 4.69 & 20 \\
\hline & $\mathrm{Ug}\left(\mathrm{kg} \cdot \mathrm{kg}^{-1}\right)$ & 0.19 & 0.03 & 0.14 & 0.20 & 0.23 & 0.14 & 20 \\
\hline & Ds $\left(\mathrm{Mg} \cdot \mathrm{dm}^{-3}\right)$ & 1.73 & 0.09 & 0.05 & 1.82 & 1.87 & 1.54 & 20 \\
\hline & $\operatorname{PT}\left(\mathrm{cm}^{3} \cdot \mathrm{cm}^{-3}\right)$ & 29.1 & 5.29 & 0.18 & 25.00 & 42.54 & 20.79 & 20 \\
\hline & Mo $\left(\mathrm{g} \cdot \mathrm{kg}^{-1}\right)$ & 20.7 & 3.99 & 0.19 & 17.00 & 30.00 & 16.00 & 20 \\
\hline \multicolumn{9}{|c|}{ Crop-livestock-forest integration } \\
\hline \multirow[t]{5}{*}{$0-0.20$} & $\mathrm{RP}(\mathrm{MPa})$ & 3.52 & 0.90 & 0.26 & 4.01 & 6.07 & 1.94 & 20 \\
\hline & $\mathrm{Ug}\left(\mathrm{kg} \cdot \mathrm{kg}^{-1}\right)$ & 0.13 & 0.01 & 0.10 & 0.12 & 0.16 & 0.12 & 20 \\
\hline & Ds $\left(\mathrm{Mg} \cdot \mathrm{dm}^{-3}\right)$ & 1.75 & 0.12 & 0.07 & 1.66 & 1.94 & 1.56 & 20 \\
\hline & $\operatorname{PT}\left(\mathrm{cm}^{3} \cdot \mathrm{cm}^{-3}\right)$ & 29.85 & 5.76 & 0.19 & 24.00 & 43.05 & 22.34 & 20 \\
\hline & $\operatorname{Mo}\left(\mathrm{g} \cdot \mathrm{kg}^{-1}\right)$ & 23.45 & 6.64 & 0.28 & 30.00 & 38.00 & 13.00 & 20 \\
\hline \multirow[t]{5}{*}{$0.20-0.40$} & $\mathrm{RP}(\mathrm{MPa})$ & 4.45 & 1.22 & 0.27 & 5.38 & 6.07 & 2.63 & 20 \\
\hline & $\mathrm{Ug}\left(\mathrm{kg} \cdot \mathrm{kg}^{-1}\right)$ & 0.16 & 0.02 & 0.10 & 0.15 & 0.21 & 0.14 & 20 \\
\hline & Ds $\left(\mathrm{Mg} \cdot \mathrm{dm}^{-3}\right)$ & 1.89 & 0.05 & 0.03 & 1.91 & 1.96 & 1.81 & 20 \\
\hline & PT $\left(\mathrm{cm}^{3} \cdot \mathrm{cm}^{-3}\right)$ & 23.12 & 2.70 & 0.12 & 21.00 & 27.52 & 17.44 & 20 \\
\hline & Mo $\left(\mathrm{g} . \mathrm{kg}^{-1}\right)$ & 13.40 & 2.37 & 0.18 & 13.00 & 18.00 & 9.00 & 20 \\
\hline \multicolumn{9}{|c|}{ Picket } \\
\hline \multirow[t]{5}{*}{$0-0.20$} & $\mathrm{RP}(\mathrm{MPa})$ & 14.82 & 4.12 & 0.28 & 14.34 & 26.74 & 8.14 & 20 \\
\hline & $\mathrm{Ug}\left(\mathrm{kg} \cdot \mathrm{kg}^{-1}\right)$ & 0.15 & 0.03 & 0.22 & 0.16 & 0.24 & 0.10 & 20 \\
\hline & Ds $\left(\mathrm{Mg} \cdot \mathrm{dm}^{-3}\right)$ & 1.65 & 0.06 & 0.04 & 1.62 & 1.75 & 1.50 & 20 \\
\hline & $\operatorname{PT}\left(\mathrm{cm}^{3} \cdot \mathrm{cm}^{-3}\right)$ & 30.95 & 4.15 & 0.13 & 27.00 & 37.64 & 21.24 & 20 \\
\hline & Mo $\left(\mathrm{g} \cdot \mathrm{kg}^{-1}\right)$ & 38.25 & 8.63 & 0.23 & 43.00 & 55.00 & 24.00 & 20 \\
\hline \multirow[t]{5}{*}{$0.20-0.40$} & $\mathrm{RP}(\mathrm{MPa})$ & 12.31 & 5.24 & 0.43 & 9.52 & 22.61 & 5.38 & 20 \\
\hline & $\mathrm{Ug}\left(\mathrm{kg} \cdot \mathrm{kg}^{-1}\right)$ & 0.16 & 0.02 & 0.11 & 0.16 & 0.22 & 0.14 & 20 \\
\hline & Ds $\left(\mathrm{Mg} \mathrm{dm}^{-3}\right)$ & 1.62 & 0.11 & 0.07 & 1.72 & 1.78 & 1.39 & 20 \\
\hline & PT $\left(\mathrm{cm}^{3} \cdot \mathrm{cm}^{-3}\right)$ & 33.45 & 5.24 & 0.16 & 33.00 & 41.68 & 22.87 & 20 \\
\hline & Mo (g.kg $\left.{ }^{-1}\right)$ & 20.70 & 3.02 & 0.15 & 19.00 & 28.00 & 16.00 & 20 \\
\hline
\end{tabular}

Revista Árvore, Viçosa-MG, v.40, n.3, p.519-527, 2016 
Table 2...

Tabela 2..

\begin{tabular}{|c|c|c|c|c|c|c|c|c|}
\hline \multirow[t]{5}{*}{$0-0.20$} & $\mathrm{RP}(\mathrm{MPa})$ & 5.25 & 1.26 & 0.24 & 5.38 & 7.45 & 2.63 & 20 \\
\hline & $\mathrm{Ug}\left(\mathrm{kg} \cdot \mathrm{kg}^{-1}\right)$ & 0.27 & 0.03 & 0.11 & 0.24 & 0.32 & 0.23 & 20 \\
\hline & Ds $\left(\mathrm{Mg} \mathrm{dm}^{-3}\right)$ & 1.37 & 0.10 & 0.07 & 1.32 & 1.52 & 1.18 & 20 \\
\hline & PT $\left(\mathrm{cm}^{3} \cdot \mathrm{cm}^{-3}\right)$ & 40.94 & 5.42 & 0.13 & 45.00 & 52.64 & 32.41 & 20 \\
\hline & $\operatorname{Mo}\left(\mathrm{g} \cdot \mathrm{kg}^{-1}\right)$ & 54.40 & 7.83 & 0.14 & 51.00 & 68.00 & 40.00 & 20 \\
\hline \multirow[t]{4}{*}{$0.20-0.40$} & $\mathrm{RP}(\mathrm{MPa})$ & 5.49 & 1.51 & 0.28 & 6.07 & 9.52 & 3.32 & 20 \\
\hline & $\mathrm{Ug}\left(\mathrm{kg} \cdot \mathrm{kg}^{-1}\right)$ & 0.26 & 0.04 & 0.17 & 0.27 & 0.35 & 0.15 & 20 \\
\hline & Ds $\left({\left.\mathrm{Mg} . \mathrm{dm}^{-3}\right)}^{-1}\right.$ & 1.52 & 0.13 & 0.09 & 1.66 & 1.77 & 1.32 & 20 \\
\hline & $\mathrm{PT}\left(\mathrm{cm}^{3} \cdot \mathrm{cm}^{-3}\right)$ & 35.18 & 5.77 & 0.16 & 39.00 & 42.81 & 20.52 & 20 \\
\hline
\end{tabular}

Ave $=$ Average $; \mathrm{SD}=$ Standard Deviation $; \mathrm{CV}=$ Coefficient of Variation; Max. $=$ Maximum; Min $=\mathrm{Min} ; \mathrm{N}=$ number of samples.

As shown in Table 3, it can be observed that for the ILP treatment on the $0-0.20 \mathrm{~cm}$ layer the only variable that entered the model, that is, that justified the RP variable was UG, showing that in the analysed data package. UG explained in $92 \%$ the variation in RP. In the layer from 0.20 to $0.40 \mathrm{~m}$ the MO, UG, DS and PT explained the RP variation in $94 \%$.

In P treatment for the layer from $0-0.20 \mathrm{~m}$. PT and MO explained $90 \%$ of RP's variation. And for the layer $0.20-0.40 \mathrm{~m}$ the variables $\mathrm{UG}, \mathrm{MO}$ and
DS justified RP's variation in $92 \%$. For the ILPF treatment in layers $0-0.20 \mathrm{~m}$ and 0.20 to $0.40 \mathrm{~m}$. the variables $\mathrm{MO}$ and DS justified the RP variations in $82 \%$ and $95 \%$, respectively.

In PIQ treatment, the RP variations were explained in $94 \%$ by the variables PT and MO for the layers $0-0.20 \mathrm{~m}$ and PT and DS for the layer $0.20-0.40$ $\mathrm{m}$. And for MN, the UF and PT explained RP in 93\% for the layer $0-0.20 \mathrm{~m}$ and $\mathrm{PT}$ in $97 \%$ for the layer $0.20-0.40 \mathrm{~m}$.

Table 3 - Selected models for estimating soil resistance to penetration (RP) versus gravimetric moisture (GM), bulk density $(D S)$, organic matter (OM) and total porosity (TP) of soils under different systems of use and management of soil and native woodland in the first year (2012/13).

Tabela 3 - Modelos selecionados para a estimativa da resistência do solo à penetração (RP) em função da umidade gravimétrica (UG), densidade do solo (DS), matéria orgânica (MO) e porosidade total (PT) de solos submetidos a diferentes sistemas de uso e manejo do solo e mata nativa, no ano $1(2012 / 13)$.

\begin{tabular}{|c|c|c|c|c|c|}
\hline Layer $(\mathrm{m})$ & Equation & $\mathrm{CV}$ & $\mathrm{R}$ & $\mathrm{Fc}$ & $\operatorname{Pr}>\mathrm{Fc}$ \\
\hline \multicolumn{6}{|c|}{ Crop-livestock integration } \\
\hline $0-0.20$ & $\mathrm{RP}=10.08-46.18 \mathrm{UG}$ & 11.29 & 0.92 & 220.65 & 0.000 \\
\hline $0.20-0.40$ & $\begin{array}{l}\mathrm{RP}=44.74+0.29 \mathrm{MO}-29.20 \mathrm{UG}- \\
18.96 \mathrm{DS}-0.17 \mathrm{PT}\end{array}$ & 7.32 & 0.94 & 75.47 & 0.000 \\
\hline \multicolumn{6}{|c|}{ Extensice grazing } \\
\hline $0-0.20$ & $\mathrm{RP}=35.75-1.28 \mathrm{PT}+0.23 \mathrm{MO}$ & 12.18 & 0.90 & 88.97 & 0.000 \\
\hline $0.20-0.40$ & $\begin{array}{l}\mathrm{RP}=-56.54-82.33 \mathrm{UG}+0.78 \mathrm{MO}+ \\
36.89 \mathrm{DS}\end{array}$ & 8.34 & 0.92 & 76.73 & 0.000 \\
\hline \multicolumn{6}{|c|}{ Crop-livestock-forest integration } \\
\hline $0-0.20$ & $\mathrm{RP}=6.42-0.12 \mathrm{MO}$ & 11.21 & 0.82 & 85.75 & 0.000 \\
\hline $0.20-0.40$ & $R P=-44.56+25.85 \mathrm{DS}$ & 6.36 & 0.95 & 350.38 & 0.000 \\
\hline \multicolumn{6}{|c|}{ Picket } \\
\hline $0-0.20$ & $\mathrm{RP}=51.07-1.51 \mathrm{PT}+0.27 \mathrm{MO}$ & 6.88 & 0.94 & 154.54 & 0.000 \\
\hline $0.20-0.40$ & $\mathrm{RP}=92.30-1.36 \mathrm{PT}-21.28 \mathrm{DS}$ & 11.07 & 0.94 & 139.09 & 0.000 \\
\hline \multicolumn{6}{|c|}{ Native woodland } \\
\hline $0-0.20$ & $\mathrm{RP}=15.58-22.12 \mathrm{UG}-0.11 \mathrm{PT}$ & 6.32 & 0.93 & 136.47 & 0.000 \\
\hline $0.20-0.40$ & $\mathrm{RP}=14.68-0.26 \mathrm{PT}$ & 4.82 & 0.97 & 637.04 & 0.000 \\
\hline
\end{tabular}


There were various alterations on the variables that influenced RP in function of the different management systems and pasture usage and native woodland and in functions of the evaluateed layers. PT was the variable that most explained RP variations. Of the 10 proposed models, PT showed up in $6^{\text {th }}$ place, followed by MO, UG and DS. On the studied conditions, it was verified that for the first year the most adequate equation to analyse $\mathrm{RP}$ was $\mathrm{MN}$, with a greater $\mathrm{R}^{2}, 0.97$. Considering the managed soil, the equation that best justified $\mathrm{RP}$, with a $\mathrm{R}^{2}$ of 0.95 , was the ILPF treatment, RP $=-44.56+25.85 \mathrm{DS}$. Both equations were obtained from layer $0.20-0.40 \mathrm{~m}$.

On the second year (2013/14), MO presented greater CV for the ILPF treatment in layers $0-0.20$ $\mathrm{m}$ and 0.20 - $0.40 \mathrm{~m}$ layers (Table 4). Meanwhile RP presented greater $\mathrm{CV}$ for the other treatments. Probably due to the use of fire as treatment for management. The fire could have consumed the haystack in a heterogenic manner, contributing to leaving areas of greater or less organic matter, which contributed to the high variability on the MO values.

All the treatments presented RP averages between 2.00 and 4.00 MPa. Among the maximum values, the treatments with greater RP values were PIQ with 6.76 $\mathrm{MPa}$ and 4.00 MPA in layers $0-0.20 \mathrm{~m}$ and 0.20 $0.40 \mathrm{~m}$ respectively, and $\mathrm{P}$ with $6.07 \mathrm{MPa}$ for both layers. Indicating that animal trampling, even in rotation circumstances, favour the soil's compaction. However, those values were ever lower than those observed on year 1, for the cited treatments. Indicating that the management system, especially PIQ, that presented high maximum RP values on year 1 , favoured the enhancement of the physical quality of the soil over the course of a year.

On the second year, the $\mathrm{R}^{2}$ were of lesser value than observed on year one. As can be observed in Table 5. For the ILP treatment, PT explained $84 \%$ of RP's variation in layers $0-0.20 \mathrm{~m}$ and for 0.20 - $0.40 \mathrm{~m}$, the variables PT and DS explained in $89 \%$ the RP variation. The $\mathrm{P}$ treatment had RP justified in $86 \%$ by the DS and UG variables, for the 0.20 $0.40 \mathrm{~m}$ layer.

The ILPF treatment on layer $0-0.20 \mathrm{~m}$ had RP variations explained in $85 \%$ by DS and for the 0.20
- $0.40 \mathrm{~m}$ layer in $90 \%$ by the UG and DS variables. The $0-0.20 \mathrm{~m}$ PIQ layer was the one that presented the model with greater representativity. The model obtained by this treatment indicated that the PT, DS and MO variables explained in $94 \%$ the RP variation, $\mathrm{RP}=-15.94-0.29 \mathrm{PT}+15.87 \mathrm{DS}+0.05 \mathrm{MO}$. Differing results than those from year 1 , focusing on the effects from the adopted PIQ management.

\section{DISCUSSION}

Tavares Filho et al. (2012) also observed high $\mathrm{CV}$ values for RP and MO. In some treatments, such as in ILP and MN, PT also presented greater CV values in both evaluated layers.

The results observed on year 1 show direct relation between PT and RP on MN and direct relation between DS and RP on ILPF. Being the treatments with less soil compaction. Tavares Filho et al. (2012) observed that DS was the variable that best explained RP. Agreeing with the obtained results of the ILPF treatment and disagreeing with the other results that pointed to $\mathrm{PT}$, followed by $\mathrm{MO}$ as the variable with greater relation with RP.

These results can be observed because of the cohesion character that is observed on the studied soil. Soils with greater cohesion character possess a stable micro structural organization, proportioning a natural density. Thus, the roots for the grass present in 4 of the 5 treatments, favoured the porous system of the soil, increasing the number of pores, which in turn gave lower RP values.

All the variables participated in the studied models. In relation to the great participation of MO on the models, indicating positive relations of the variable with RP, it can be justified by the greater deposition of MO in all treatments, by the grass or by the decomposition of the haystack or by the great quantity of leaves and sticks that could be deposited on the superficial layer of MN and ILPF.

Ribon and Tavares Filho (2004) also observed great MO contribution on the proposed models. Possible results to be observed because of MO's capacity to favour cementing of the soil's particles, providing the formation of block structures that negatively influences $=\mathrm{RP}(\mathrm{SÁ}$; SANTOS, 2005). 
Table 4 - Statistical moments of year 2 for variables analized in layers $0-0.2$ and $0.2-0.4 \mathrm{~m}$ for soils under different land use systems and soil management and native woodland.

Tabela 4 - Momentos estatísticos do ano 2 para as variáveis analisadas nas camadas de 0-0,2 e 0,2-0,4m, para solos submetidos a diferentes sistemas de uso e manejo do solo e mata nativa.

\begin{tabular}{|c|c|c|c|c|c|c|c|c|}
\hline Layer $(\mathrm{m})$ & Variable & Ave. & $\mathrm{SD}$ & $\mathrm{CV}$ & Mod. & Max. & Min & $\mathrm{N}$ \\
\hline \multicolumn{9}{|c|}{ Crop-livestock integration } \\
\hline \multirow[t]{5}{*}{$0-0.20$} & $\mathrm{RP}(\mathrm{MPa})$ & 2.76 & 0.56 & 0.20 & 2.62 & 4.00 & 1.93 & 20 \\
\hline & $\mathrm{Ug}\left(\mathrm{kg} \cdot \mathrm{kg}^{-1}\right)$ & 0.18 & 0.01 & 0.08 & 0.18 & 0.21 & 0.16 & 20 \\
\hline & Ds $\left(\mathrm{Mg} \cdot \mathrm{dm}^{-3}\right)$ & 1.86 & 0.07 & 0.04 & 1.88 & 1.97 & 1.66 & 20 \\
\hline & PT $\left(\mathrm{cm}^{3} \cdot \mathrm{cm}^{-3}\right)$ & 24.30 & 4.86 & 0.20 & 25.00 & 34.00 & 13.00 & 20 \\
\hline & $\operatorname{Mo}\left(\mathrm{g} \cdot \mathrm{kg}^{-1}\right)$ & 23.00 & 7.94 & 0.35 & 34.00 & 34.00 & 12.00 & 20 \\
\hline \multirow[t]{5}{*}{$0.20-0.40$} & $\mathrm{RP}(\mathrm{MPa})$ & 2.79 & 0.90 & 0.32 & 1.938 & 5.38 & 1.93 & 20 \\
\hline & $\mathrm{Ug}\left(\mathrm{kg} \cdot \mathrm{kg}^{-1}\right)$ & 0.22 & 0.01 & 0.05 & 0.22 & 0.25 & 0.20 & 20 \\
\hline & Ds $\left(\mathrm{Mg} \cdot \mathrm{dm}^{-3}\right)$ & 1.80 & 0.05 & 0.03 & 1.81 & 1.91 & 1.70 & 20 \\
\hline & $\mathrm{PT}\left(\mathrm{cm}^{3} \cdot \mathrm{cm}^{-3}\right)$ & 26.60 & 4.13 & 0.16 & 23.00 & 39.00 & 20.00 & 20 \\
\hline & $\operatorname{Mo}\left(\mathrm{g} \cdot \mathrm{kg}^{-1}\right)$ & 13.60 & 4.76 & 0.35 & 11.00 & 31.00 & 8.00 & 20 \\
\hline \multicolumn{9}{|c|}{ Extensive grazing } \\
\hline \multirow[t]{5}{*}{$0-0.20$} & $\mathrm{RP}(\mathrm{MPa})$ & 3.69 & 0.94 & 0.25 & 2.62 & 6.07 & 2.62 & 20 \\
\hline & $\mathrm{Ug}\left(\mathrm{kg} \cdot \mathrm{kg}^{-1}\right)$ & 0.23 & 0.02 & 0.09 & 0.23 & 0.28 & 0.20 & 20 \\
\hline & Ds $\left({\left.\mathrm{Mg} . \mathrm{dm}^{-3}\right)}^{-1}\right.$ & 1.76 & 0.07 & 0.04 & 1.80 & 1.95 & 1.65 & 20 \\
\hline & $\mathrm{PT}\left(\mathrm{cm}^{3} \cdot \mathrm{cm}^{-3}\right)$ & 26.15 & 3.24 & 0.12 & 26.00 & 34.00 & 20.00 & 20 \\
\hline & $\operatorname{Mo}\left(\mathrm{g} \cdot \mathrm{kg}^{-1}\right)$ & 32.70 & 7.09 & 0.22 & 41.00 & 50.00 & 22.00 & 20 \\
\hline \multirow[t]{5}{*}{$0.20-0.40$} & $\mathrm{RP}(\mathrm{MPa})$ & 3.41 & 0.91 & 0.26 & 3.31 & 6.07 & 1.93 & 20 \\
\hline & $\mathrm{Ug}\left(\mathrm{kg} \cdot \mathrm{kg}^{-1}\right)$ & 0.37 & 0.44 & 1.19 & 0.27 & 2.30 & 0.20 & 20 \\
\hline & $\mathrm{Ds}\left(\mathrm{Mg} \cdot \mathrm{dm}^{-3}\right)$ & 1.67 & 0.07 & 0.04 & 1.74 & 1.85 & 1.56 & 20 \\
\hline & $\mathrm{PT}\left(\mathrm{cm}^{3} \cdot \mathrm{cm}^{-3}\right)$ & 29.15 & 3.61 & 0.12 & 28.00 & 35.00 & 23.00 & 20 \\
\hline & $\operatorname{Mo}\left(\mathrm{g} \cdot \mathrm{kg}^{-1}\right)$ & 19.10 & 2.68 & 0.14 & 20.00 & 25.00 & 15.00 & 20 \\
\hline \multicolumn{9}{|c|}{ Crop-livestock-forest integration } \\
\hline \multirow[t]{5}{*}{$0-0.20$} & $\mathrm{RP}(\mathrm{MPa})$ & 2.17 & 0.55 & 0.25 & 2.62 & 3.31 & 1.24 & 20 \\
\hline & $\mathrm{Ug}\left(\mathrm{kg} \cdot \mathrm{kg}^{-1}\right)$ & 0.17 & 0.02 & 0.13 & 0.16 & 0.23 & 0.14 & 20 \\
\hline & $\mathrm{Ds}\left(\mathrm{Mg} \cdot \mathrm{dm}^{-3}\right)$ & 1.77 & 0.13 & 0.07 & 1.64 & 1.93 & 1.47 & 20 \\
\hline & PT $\left(\mathrm{cm}^{3} \cdot \mathrm{cm}^{-3}\right)$ & 28.00 & 5.10 & 0.18 & 25.00 & 42.00 & 22.00 & 20 \\
\hline & $\operatorname{Mo}\left(\mathrm{g} \cdot \mathrm{kg}^{-1}\right)$ & 26.00 & 6.46 & 0.25 & 32.00 & 42.00 & 15.00 & 20 \\
\hline \multirow[t]{5}{*}{$0.20-0.40$} & $\mathrm{RP}(\mathrm{MPa})$ & 2.42 & 0.69 & 0.29 & 1.93 & 4.00 & 1.24 & 20 \\
\hline & $\mathrm{Ug}\left(\mathrm{kg}^{\mathrm{kg}} \mathrm{kg}^{-1}\right)$ & 0.19 & 0.04 & 0.19 & 0.19 & 0.27 & 0.10 & 20 \\
\hline & Ds $\left(\mathrm{Mg} \cdot \mathrm{dm}^{-3}\right)$ & 1.85 & 0.07 & 0.04 & 1.91 & 2.00 & 1.74 & 20 \\
\hline & $\mathrm{PT}\left(\mathrm{cm}^{3} \cdot \mathrm{cm}^{-3}\right)$ & 24.45 & 4.04 & 0.17 & 25.00 & 31.00 & 16.00 & 20 \\
\hline & $\operatorname{Mo}\left(\mathrm{g} \cdot \mathrm{kg}^{-1}\right)$ & 14.10 & 2.34 & 0.17 & 13.00 & 18.00 & 10.00 & 20 \\
\hline \multicolumn{9}{|c|}{ Picket } \\
\hline \multirow[t]{5}{*}{$0-0.20$} & $\mathrm{RP}(\mathrm{MPa})$ & 3.86 & 1.24 & 0.32 & 4.00 & 6.76 & 1.93 & 20 \\
\hline & $\mathrm{Ug}\left(\mathrm{kg} \cdot \mathrm{kg}^{-1}\right)$ & 0.20 & 0.01 & 0.04 & 0.20 & 0.22 & 0.19 & 20 \\
\hline & Ds $\left(\mathrm{Mg} \mathrm{dm}^{-3}\right)$ & 1.70 & 0.06 & 0.03 & 1.73 & 1.81 & 1.58 & 20 \\
\hline & $\mathrm{PT}\left(\mathrm{cm}^{3} \cdot \mathrm{cm}^{-3}\right)$ & 31.75 & 3.24 & 0.10 & 32.00 & 39.00 & 26.00 & 20 \\
\hline & $\operatorname{Mo}\left(\mathrm{g} \cdot \mathrm{kg}^{-1}\right)$ & 33.35 & 10.90 & 0.33 & 24.00 & 58.00 & 19.00 & 20 \\
\hline \multirow{5}{*}{$0.20-0.40$} & $\mathrm{RP}(\mathrm{MPa})$ & 2.69 & 0.61 & 0.23 & 2.62 & 4.00 & 1.93 & 20 \\
\hline & $\mathrm{Ug}\left(\mathrm{kg} \cdot \mathrm{kg}^{-1}\right)$ & 0.21 & 0.01 & 0.03 & 0.22 & 0.23 & 0.20 & 20 \\
\hline & Ds $\left(\mathrm{Mg} . \mathrm{dm}^{-3}\right)$ & 1.68 & 0.08 & 0.05 & 1.66 & 1.85 & 1.56 & 20 \\
\hline & $\mathrm{PT}\left(\mathrm{cm}^{3} \cdot \mathrm{cm}^{-3}\right)$ & 32.15 & 4.36 & 0.14 & 33.00 & 38.00 & 23.00 & 20 \\
\hline & $\operatorname{Mo}\left(\right.$ g. $\left.\mathrm{kg}^{-1}\right)$ & 16.10 & 2.55 & 0.16 & 18.00 & 21.00 & 12.00 & 20 \\
\hline
\end{tabular}


Table 4...

Tabela 4 ..

\begin{tabular}{|c|c|c|c|c|c|c|c|c|}
\hline & & & Native & land & & & & \\
\hline $0-0.20$ & $\mathrm{RP}(\mathrm{MPa})$ & 2.11 & 0.53 & 0.25 & 1.93 & 3.31 & 1.24 & 20 \\
\hline & $\mathrm{Ug}\left(\mathrm{kg} \cdot \mathrm{kg}^{-1}\right)$ & 0.42 & 0.03 & 0.07 & 0.44 & 0.47 & 0.36 & 20 \\
\hline & Ds $\left(\mathrm{Mg} \mathrm{dm}^{-3}\right)$ & 1.34 & 0.09 & 0.07 & 1.38 & 1.50 & 1.16 & 20 \\
\hline & PT $\left(\mathrm{cm}^{3} \cdot \mathrm{cm}^{-3}\right)$ & 42.10 & 4.54 & 0.11 & 38.00 & 50.00 & 34.00 & 20 \\
\hline & $\operatorname{Mo}\left(\mathrm{g} \cdot \mathrm{kg}^{-1}\right)$ & 39.85 & 6.59 & 0.17 & 44.00 & 51.00 & 25.00 & 20 \\
\hline $0.20-0.40$ & $\mathrm{RP}(\mathrm{MPa})$ & 2.17 & 0.73 & 0.34 & 1.93 & 4.00 & 1.24 & 20 \\
\hline & $\mathrm{Ug}\left(\mathrm{kg} \cdot \mathrm{kg}^{-1}\right)$ & 0.42 & 0.07 & 0.15 & 0.42 & 0.59 & 0.31 & 20 \\
\hline & Ds $\left(\mathrm{Mg} \mathrm{dm}^{-3}\right)$ & 1.37 & 0.12 & 0.09 & 1.34 & 1.67 & 1.14 & 20 \\
\hline & PT $\left(\mathrm{cm}^{3} \cdot \mathrm{cm}^{-3}\right)$ & 40.89 & 5.45 & 0.13 & 33.00 & 49.00 & 32.00 & 20 \\
\hline & $\operatorname{Mo}\left(\mathrm{g} \cdot \mathrm{kg}^{-1}\right)$ & 34.90 & 7.06 & 0.20 & 37.00 & 44.00 & 15.00 & 20 \\
\hline
\end{tabular}

$\mathrm{M}$ Ave $=$ Average $\mathrm{SD}=$ Standard Deviation $\mathrm{CV}=$ Coefficient of Variation; Max. $=$ Maximum Min $=$ Min; $\mathrm{N}=$ number of samples.

Table 5 - Selected models for estimating soil resistance to penetration (RP) versus gravimetric moisture (GM), bulk density (DS), organic matter (OM) and total porosity (TP) of soils under different systems of use and management of soil and native woodland in year $2(2013 / 14)$.

Tabela 5 -Modelos selecionados para a estimativa da resistência do solo à penetração (RP) em função da umidade gravimétrica (UG), densidade do solo (DS), matéria orgânica (MO) e porosidade total (PT) de solos submetidos a diferentes sistemas de uso e manejo do solo e mata nativa, no ano 2 (2013/14).

\begin{tabular}{|c|c|c|c|c|c|}
\hline Layer $(\mathrm{m})$ & Equation & $\mathrm{CV}$ & $\mathrm{R}$ & Fc & $\mathrm{Pr}>\mathrm{Fc}$ \\
\hline \multicolumn{6}{|c|}{ Crop-livestock integration } \\
\hline $0-0.20$ & $\mathrm{RP}=5.41-0.11 \mathrm{PT}$ & 8.34 & 0.84 & 99.93 & 0.000 \\
\hline $0.20-0.40$ & $\mathrm{RP}=-59.57+31.48 \mathrm{DS}-0.20 \mathrm{PT}$ & 10.85 & 0.89 & 78.1 & 0.000 \\
\hline \multicolumn{6}{|c|}{ Extensive grazing } \\
\hline $0-0.20$ & $\mathrm{RP}=-6.66+6.86 \mathrm{DS}-0.05 \mathrm{MO}$ & 9.66 & 0.86 & 60.03 & 0.000 \\
\hline $0.20-0.40$ & $\mathrm{RP}=-2.23+6.73 \mathrm{DS}-20.59 \mathrm{UG}$ & 9.71 & 0.87 & 65.54 & 0.000 \\
\hline \multicolumn{6}{|c|}{ Crop-livestock-forest integration } \\
\hline $0-0.20$ & $R P=-4.70+3.88 D S$ & 10.67 & 0.83 & 92.7 & 0.000 \\
\hline $0.20-0.40$ & $\mathrm{RP}=-1.47-1178 \mathrm{UG}+3.31 \mathrm{DS}$ & 9.05 & 0.9 & 91.37 & 0.000 \\
\hline \multicolumn{6}{|c|}{ Picket } \\
\hline $0-0.20$ & $\mathrm{RP}=-15.94-0.29 \mathrm{PT}+15.87 \mathrm{DS}$ & 8.15 & 0.94 & 98.06 & 0.000 \\
\hline
\end{tabular}

\section{CONCLUSION}

The equations that better estimated the soil's resistence to penetration were $\mathrm{RP}=14.68-0.26 \mathrm{PT}$ for MN (native woodland) on layer $0.20-0.40 \mathrm{~m}$ and $\mathrm{RP}=-44.56+25.85 \mathrm{DS}$ for layer $0.20-0.40 \mathrm{~m}$ for ILPF treatment, with $\mathrm{R}^{2}$ indexes of 0.97 and 0.95 , respectively on year 1 . For year 2 , the equation that better estimated the soil's resistence to penetration was obtained by the PIQ treatment, RP $=-15.94-$ $0.29 \mathrm{PT}+15.87 \mathrm{DS}+0.05 \mathrm{MO}$, with a $\mathrm{R}^{2}$ value of 0.94 .

The variation on the best $\mathrm{R}^{2}$ values were probably observed due to the use of fire as management for
ILPF, which causes moisture and organic matter loss of the soils, contributing to greater resistance to penetration.

Over the passage of a year, the adopted management procedures provided a better physical quality of the soil and contributed to the lesser expression of the soil's cohesion.

On the second year of experimentation, a positive relation between the soil's density and it's resistence to penetration and a negative relation between the soil's density and its gravimetric moisture were observed. 


\section{ACKNOWLEDGEMENT}

CNPQ for providing the research grant and technological innovation to the first author.

\section{REFERENCES}

ALBUQUERQUE, J.A.; SANGOI, I.; ENDER, M. Efeitos da integração lavoura-pecuaria nas propriedades fisicas do solo e caracteristicas da cultura do milho. Revista Brasileira de Ciência do Solo, v.25, p.717-723, 2001.

ARAÚJO, R.; GOEDERT, W.J.; LACERDA, M.P.C. Qualidade de um solo sob diferentes usos e sob Cerrado nativo. Revista Brasileira de Ciência do Solo, v.31, p.1099-1108, 2007.

DIAS, F.L.F.; MAZZA, J. A.; MATSUOKA, S.; PERECIN, D.; MAULE, R. F. Relação entre produtividade, clima, solos e variedades de canade-açúcar na região noroeste do Estado de São Paulo. Revista Brasileira de Ciência do Solo, 23:627-634, 1999.

EMPRESA BRASILEIRA DE PESQUISA AGROPECUÁRIA - EMBRAPA. Manual de Métodos de análise de solo. $2^{\mathrm{a}}$. ed. Rio de Janeiro: 2011. 225p.

EMPRESA BRASILEIRA DE PESQUISA AGROPECUÁRIA - EMBRAPA. Sistema brasileiro de classificação de solos. $3^{\mathrm{a}}$. ed. Brasília: 2013.353p.

IMHOFF, S.; SILVA, A.P.; TORMENA, C.A. Aplicações da curva de resistência no controle da qualidade física de hum pastagem solo de soluço. Pesquisa Agropecuária Brasileira, v.35, p.1493-1500, 2000.

LEONEL, C.L.; CENTURION, M. A. P. C.; CENTURION, J. F.; BEUTLER, A. N.; FREDDI, O. S. Relação da compactação do solo com a cultura do amendoim. Bioscience Journal, v.23, n.1, p.70-81, 2007.

LIMA, C.L.R.; REICHERT, J. M.; REINERT, D. J.; SUZUKI, L. E. A. S.; DALBIANCO, L. Densidade crítica ao crescimento de plantas considerando água disponível e resistência à penetração de um
Argissolo Vermelho distrófico arênico. Ciência Rural, v.37, p.1166-1169, 2007.

RIBON, A.A.; TAVARES FILHO, J. Estimativa da resistência mecânica à penetração de um latossolo vermelho sob cultura perene no norte do estado do Paraná. Revista Brasileira de Ciência do Solo, v.32, p.1817-1825, 2008.

RIBON, A. A.; TAVARES FILHO, J.;

FERNANDES, K. L.; HERMÓGENES, V. T. L. Seleção de método estatístico para modelos de estimativa da qualidade física de solos argilosos. Revista de Argicultura, v.89, n.1, p.29-40, 2014.

RIBON, A.A.; TAVARES FILHO, J. Model propositions for the estimation of the physical quality of a Yellow Red Latosol (Oxisol) under pasture. Brazilian Archives of Biology and Technology, v.47, n.1, p.25-31, 2004.

SÁ, M.A.C.; SANTOS JUNIOR, J.D.G. Compactação do solo: Conseqüências para o crescimento vegetal. Planaltina: Embrapa Cerrados, 2005. 26p. (Documentos, 136).

STOLF, R. Teoria e teste experimental de fórmulas de transformação dos dados de penetrômetro de impacto em resistência do solo.

Revista Brasileira de Ciência do Solo, v.15, n.2, p.229-35, 1991.

STOLF, R.; FERNANDES, J.; FURLANI NETO, V.L Penetrômetro de impacto IAA/ PLANALSUCAR-STOLF; recomendação para seu uso. STAB, Açúcar Alcool

Subprodutos, v.1, p.18-23, 1983.

TAVARES FILHO, J.; FELTRAN, C. T. M.; OLIVEIRA, J. F.; ALMEIDA, E. Modelling of soil penetration resistance for an oxisol under notillage. Revista Brasileira de Ciência do Solo, v.36, n.1, p.89-95, 2012.

TAVARES FILHO, J.; RIBON, A.A. Resistência do Solo á Penetração em Resposta ao Numero de Amostras e Tipo de Amostragem. Revista Brasileira de Ciência do Solo, v.32, p.487-494, 2008.

Revista Árvore, Viçosa-MG, v.40, n.3, p.519-527, 2016 